\title{
Land Use Dynamics and Expansion of the Built-Up Area in Benin City, Nigeria
}

\author{
Olayiwola, A. M.
}

\author{
Department of Geography, Obafemi Awolowo University, Ile-Ife, Nigeria \\ amolayiwola@oauife.edu.ng/olaadewale@yahoo.com/olaadewale1@gmail.com
}

Igbavboa, O. E.

Department of Geography, Obafemi Awolowo University, Ile-Ife, Nigeria odion22@yahoo.com

\section{Doi:10.5901/mjss.2014.v5n20p2506}

\section{Abstract}

\begin{abstract}
The dynamics of the urban form in relation to anthropogenic activities leaves much to be desired in its study for proper and timely planning of the urban environment. This, therefore, brings to bear the urgent need for the use of modern digital town planning techniques that can easily provide accurate data for efficient planning preference to the continual use of conventional analogue methods which make town planning data readily available. In view of this, this study monitored the growth of Benin City between 1987 and 2008 using the contemporary remote sensing and geographic information system (GIS) techniques. Thus, the study aimed at examining the trend of urban growth in the study area with a view to examining its consequence on the land use pattern. The methods adopted for this research involves the use of remotely sensed data from Landsat TM and Landsat ETM. Ground truthing was also carried out to corroborate the data from the satellite images. Secondary data from the literature relevant to the study were also obtained. The results showed that Benin City was expanding rapidly leading to an inverse spill over effect on the vegetation resources of the peripheral area. This has placed a serious burden on the Department of Town/ Land Use Planning saddled with the responsibility to properly integrate these adjoining rural settlements into the already existing urban form. In addition, the results showed that at the rate Benin-City was expanding, if not checked will in no distant future pose a threat to the micro-climate of the area and food production.
\end{abstract}

Keywords: Remote sensing, geographic information system (GIS), urban growth, sustainable development, urban sprawl, Benin City

\section{Introduction}

Urban environment is one of the most dynamic systems on earth and rapid urbanization has been a major development in most parts of the world. Although cities could be regarded as relatively small in number, they contain nearly half of the world's total population. The great effects of urban concentration became noticed in the $19^{\text {th }}$ century with the alarming rate of urban population, and this trend continues. De Sherbinin et al (2002) noted that several decades of accelerating urban growth have exerted profound environmental socio-economic impacts felt in every parts of the world. This continuously growing population culminates in overcrowding resulting in pressure on the land and, consequently, becomes a burden to limited civic cycle amenities forcing the "middle class" as well as the builders to move to outlying suburbs, a phenomenon called urban growth or sprawl.

The European Environment Agency (2006) likened urban sprawl to unplanned, incremental urban development, characterized by low-density mix of land uses on the urban fringe. It is the physical pattern of low-density expansion of large urban areas mainly into the surrounding agricultural areas. Hence, urban growth or sprawl is highly interlinked to increase in population size and territorial expansion. Burak and Karen (2008) identified three phases of urban growth and develop scenarios to evaluate the impact of urban growth on several environmental indicators: land use, air quality, and demand for water and energy. He opined that by 2020 all developable land will be urban and the increase in the number of vehicles will be a major source of air pollution.

Unchecked and unmanaged urban growth has been attributed to lack of adoption of efficient and effective urban planning tools. In effect, sustainable development is often proposed. UN-Habitat (2008) presented a global report on planning sustainable cities, which reveals that developed countries have adopted some innovative approaches in recent decades for achieving a sustainable urban environment. Among such approaches are strategic spatial planning, use of spatial planning to integrate public sector functions, new land regularization (including land value and monitoring) and 
management approaches. Other approaches include participatory processes and partnerships at the neighbourhood level, and planning for new and more sustainable spatial forms like compact cities and new urbanism. However, contrary is the case in developing countries where older forms of master planning still persist. This approach fails to accommodate the ways of life of the majority of the inhabitants in rapidly growing and largely poor and informal cities. It has not been flexible to planning spatial structures of the cities which have enhanced the unbridled expansion of cities as well as laxity in monitoring and evaluation of urban plans. This has over time often directly contributed to social and spatial marginalization.

Remote sensing is a means of non-contact data capture and GIS is a tool for data management. The integration of both systems provides effective and efficient tool for urban planning and management. For instance, Shupeng, Shan and Chuangji (2000) integrated remote sensing and GIS application in the analysis of urban growth in China. They emphasized the early applications of remote sensing to environmental monitoring and resources investigation and its achievements in China since the early 1980s. Taking Beijing, Shanghai, and Dongguan as examples, they focused on urban expansion in China in relation to its spatial distribution patterns and temporal change. The regional differences in the development of urban GIS in China were clearly identified.

Weng (2001) used remote sensing and GIS to relate urban growth studies to hydrological modelling in Zhujiang Delta of southern China, where dramatic urban growth has created severe problems in water resources management. Impacts of urban growth on surface runoff and the rainfall-runoff relationship were examined by linking the two modelling results with spatial analysis techniques. The results revealed a notably uneven spatial pattern of urban growth and an increase of $8.10 \mathrm{~mm}$ in annual runoff depth during the 1989-1997 periods. An area that experienced more urban growth had a greater potential for increasing annual surface runoff. Highly urbanized areas were more prone to flooding. He concluded that urbanization lowered potential maximum storage, and thus increased runoff coefficient values.

Srvastava (2002) used remote sensing and GIS techniques to monitored urban sprawl in the Jharia coalfields area in India between 1974 and 1990. He explained that the irregular growth of urban areas consumes agricultural and flat upland on their periphery and such developments become a liability when they become part of the city as far as infrastructural facilities are concerned. He explained that urban sprawl and changes in urban status of urban areas from 1974 to 1990 indicated a major increase of about 60\% (290 sq. km) in the total study area of $720 \mathrm{sq} . \mathrm{km}$ of Jharia Coalfield. He further stated that urban areas grew only in and around working sites prior to nationalization of coal mining thus, recording no significant urban sprawl. The much increase was recorded during 16 years of nationalization when township developed away from overcrowded urban areas particularly for providing clean environment of living. In addition, he discovered that the built up areas were seen more in the eastern part of the study area and that significant growth occurred in the north-east. Urban sprawl had left only derelict land on the rural-urban fringe spoiling the aesthetic value of landscape and hindering further development. The change in the geo-hydrological environment affected adversely the greenery and vegetation cover. He concluded that there has been a general degradation in the environment of the region and that the study had demonstrated the importance of integrating satellite remote sensing images with other geographic maps and GIS database.

The National Research Council (NRC, 2003) asserts that in South Carolina, Richland County uses remote sensing data routinely with GIS to monitor the county's civil infrastructure and their present conditions to track urban growth or sprawl. Boulder County in the State of Colorado used integrated remote sensing and GIS data in public health, land use/land cover, parks and road maintenance applications. In addition, Adepoju (2005) remarked that remote sensing combined with GIS applications have been effective in monitoring large urban expanses and predicting future trends in urban areas of high income countries such as London (England), Berlin (Germany) and Washington D.C. in the United States of America. Adepoju (2005) in 'sensing for sprawl' in Nigeria, affirmed that only 30\% of houses in Lagos have an approved plan while $60 \%$ of residences in Victoria Island, Lagos have been converted to offices and banks. Also he identified that parkland meant for public recreational use has been illegally parcelled off for private homes. In addition, he reports that in Abuja, a petrol station was illegally built on a location meant to be a school play-ground.

Adegboyega and Aguda (2010) considered the spatio-temporal analysis of urban sprawl in a fringe area around Ibadan, South-western Nigeria using remote sensing and GIS. They demonstrated the ability of remote sensing and GIS in providing quantitative measurement of urban sprawl pattern and trend at Egbeda Local Government Area in Ibadan. They discovered that by using aerial photos (1964 and 1974); SPOT-XS, 1986; SPOT-P, 1993 and Landsat ETM+, 2000, the urbanized part of Egbeda Local Government Area which only covered about $233 \mathrm{~km}^{2}$ in 1964 had reached $76.50 \mathrm{~km}^{2}$ in 2000 and a projection of $191.7 \mathrm{~km}^{2}$ was made for 2020 . The study also revealed that low density sprawl was found to predominate the area between 1986 and 2000. In examining the effect of sprawl on agricultural land and the periphery of the urban form they concluded that not only was a vast agricultural land consumed by the sprawl experienced in the area, but that about 32 villages had already been lost to the sprawling growth. 
Hasi and Yoshiki (2012) investigated the spatial and temporal dynamics of urban growth in the Tokyo, Japan, metropolitan area by using remote sensing imagery from 1972 to 2011 and census population data from 1970 to 2010 . They found that the built-up density decreased in the metropolitan inner core as the city center experienced depopulation. Thus, there was a large population loss in the core of the city as many residents migrated to outlying suburban areas. This suburbanization process enormously expanded urban areas over a short time. Along with suburban population growth, much cropland area has been used up for constructional activities.

Ade and Afolabi (2013) carried out change detection analysis in the Federal Capital Territory of Nigeria from 19872007 by monitoring urban sprawl using remote sensing and GIS techniques with Landsat TM (1987), Landsat ETM (1999) and Nigeriasat-1 (2007). They discovered that the built up area increased from $8 \%$ in 1987 to $22 \%$ in 2007, rockoutcrop decreased from $74 \%$ to $37 \%$, vegetation decreased from $40 \%$ to $17 \%$, while the area occupied by water body has remained constant overtime. They also made projection for the population in the next nine years and expected the population to have reached 1,925,464 which is about 37\%. They concluded that to support this increase in population and physical growth rate observed, constant monitoring of the urban growth is required to be sustained.

There has been rapid population increase and attendant urban expansion in Benin City, Nigeria, in recent years. Benin City, with well-connected intra- and inter-city route networks, provides a gateway to the eastern parts of Nigeria. However, unplanned and unmanaged urban growth at the peripheral parts of the city has not received adequate attention of researchers. In view of this, the study aimed at determining the rate and extent of changes in urban growth of Benin City, Edo State, between 1987 and 2008. This is with the view of assessing the impact of urban growth on land use/land cover pattern in the study area. Also, the study predicted future urban expansion of the area up to 2050.

\section{The Study Area}

The study was conducted in Benin City, the capital of Edo State, Nigeria. Benin City lies within latitudes $6^{\circ} 12^{\prime} 38.36^{\prime \prime} \mathrm{N}$ and $6^{\circ} 27^{\prime} 25.00^{\prime \prime} \mathrm{N}$; and longitudes $5^{\circ} 29^{\prime} 46.03^{\prime \prime} \mathrm{E}$ and $5^{\circ} 45^{\prime} 00.41^{\prime \prime} \mathrm{E}$ (Fig. 1). The city is made-up of three Local Government Areas (L. G. As), namely: Egor, Ikpoba-Okha and Oredo L. G. As. Benin City is located at a very strategic position and serves as a gateway to the eastern part of the country. The road network in Benin City is such that most of the major roads originated in a radial pattern from the city centre 'King's Square' to different directions in the city. This radial route network was from the city centre enhanced interconnectivity between the core and the remaining part of the city.

Benin City falls within the tropical climate; the annual average temperature is about $27^{\circ} \mathrm{C}$ and the annual rainfall is about $2000 \mathrm{~mm}$. Benin City experiences two major seasons, the wet season which lasts from March to October and the dry season which lasts for the remaining parts of the year. The influence of the cold, dry and dusty harmattan wind, which results in a considerable drop in the atmospheric humidity, is felt during the dry season between the months of October and February. The general topography of Benin City can be described as low and sloping gently from about 105m above sea level in the North-East to about $55 \mathrm{~m}$ in the South-West. The basement rocks are of sedimentary origin. The eastern edge of Benin City is sloppy hill towards the Ikpoba River that drains the eastern part of the city, while the western edges slope gently towards the western part of the city. The ferrasols are the major soil types found in Benin City. They are the deeply weathered red and yellowish brown soils. They have abundant free iron oxides but generally without a lateritic pan layer (Filani, 1995). The soils are mainly loams, sandy-loams and sandy-clay-loams. They suffer from excessive internal drainage and leaching, which gives them a strong acid reaction. In effect of these physical characteristics, the natural vegetation of Benin City is rain forest rich in such species as Obeche, Iroko among others and therefore lumbering and timber processing are major economic activities in the area.

Asides the occupations offered by the natural environment, Benin City has a flourishing craft industry which dates back to the twelfth century. The industry consists of craft and ivory carving, weaving and bronze casting. Farming and hunting were also major economic activities. However, today, craft industries have given way to manufacturing industries, service industries and trading activities. 


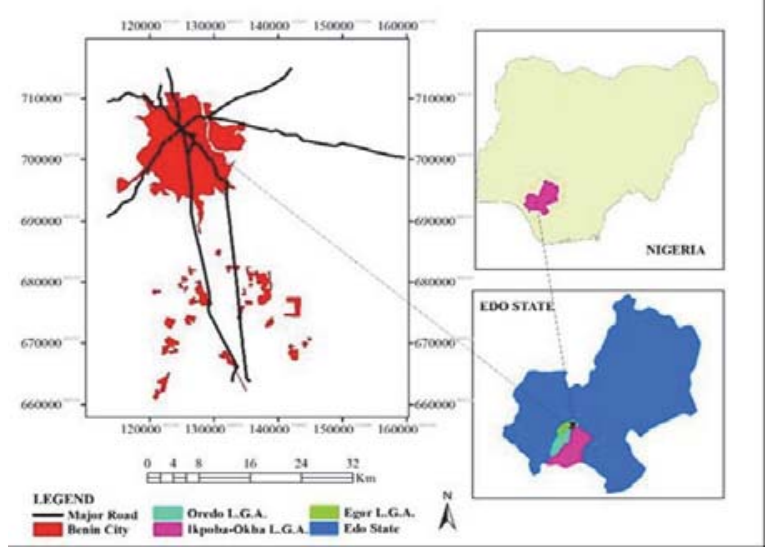

Fig. 1: Map of the Study Area

\section{Methodology}

Data for this study were acquired from both primary and secondary sources. Whereas primary sources include Global Positioning System (GPS) and satellite imageries, secondary data were sourced from topographical map of Benin City (1986), and population data. The characteristics of the satellite images used in this study are contained in Table 1.

Table 1: Characteristics of Satellite Imageries used

\begin{tabular}{|l|l|l|l|l|l|l|}
\hline Landsat Scene & Acquisition Date & Location on WRS & Dimensions (in Pixels) & Spatial Resolution & Source & Band \\
\hline Landsat TM & $21 / 12 / 1987$ & P189R056 & $1789 \times 1614$ & $28.5 \mathrm{~m} \times 28.5 \mathrm{~m}$ & RECTAS, OAU* $^{*}$ & $5,4,3$ \\
\hline Landsat TM & $21 / 12 / 2000$ & P189R056 & $1789 \times 1614$ & $28.5 \mathrm{~m} \times 28.5 \mathrm{~m}$ & RECTAS, OAU $^{*}$ & $5,4,3$ \\
\hline Landsat ETM+ & $21 / 12 / 2008$ & P189R056 & $1789 \times 1614$ & $28.5 \mathrm{~m} \times 28.5 \mathrm{~m}$ & SPDC, Warri $^{*}$ & $5,4,3$ \\
\hline
\end{tabular}

The methodological procedure adopted in this study is illustrated in Fig. 2.

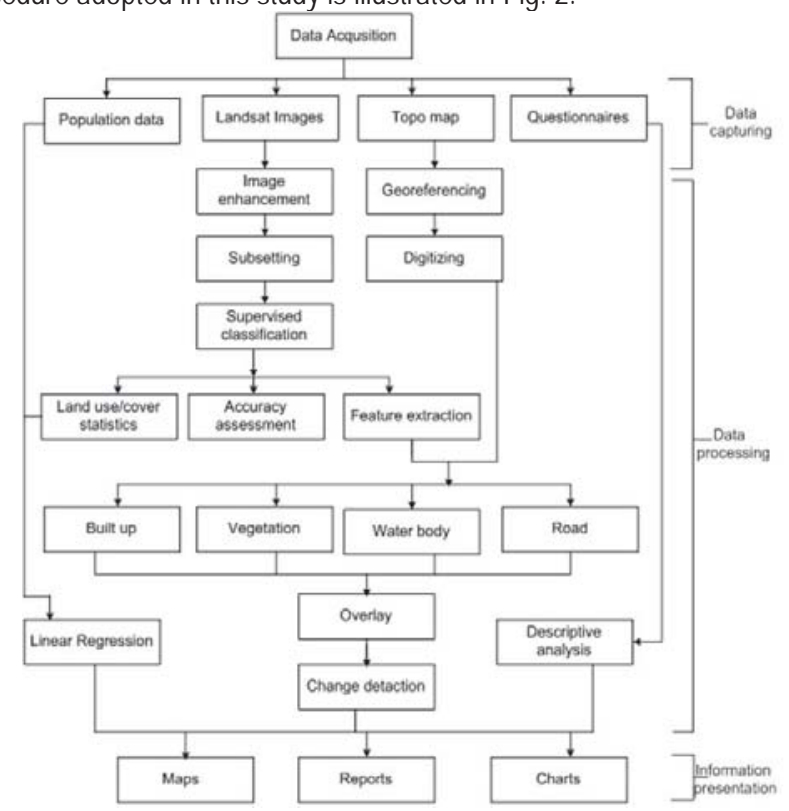

Fig. 2: Flow Chart of the Research Methods 
False colour composite images were derived from the satellite images (Landsat TM 1987, and 2000 and Landsat ETM+ 2008) for proper visibility of the land use/ land cover classes through a combination of bands 5, 4 and 3 of the Landsat images. The images were then sub-mapped to extract the areas of interest, which are built-up areas, vegetation and water body. Supervised classification was employed with the maximum likelihood algorithm to produce segment maps which delineated areas covered by each land use category on the classified image. Geo-spatial techniques involved overlay operations which was adopted to analyse change detection.

The total area and percentage covered by each land cover were determined to ascertain the growth trend, spatial spread pattern and also for prediction of future urban growth. Using the geometric growth model, the physical elements and population of Benin City were projected to the year 2050. In addition, Cellular Automata Model of landuse forecasting was used to predict changes in the built up area of Benin City. Slope and intercept regression analysis was adopted to determine the trend in time series. Whereas, the correlation coefficient $(r)$ indicated the strength and direction of growth, the rate of this trend is indicated by the value of the slope of the regression.

\section{Results and Discussion}

\subsection{Population Changes in Benin City (1800-2008)}

Table 2 shows the inter-temporal changes in the population of Benin City between 1800 and 2008. The population of Benin City increased at a growth rate of 271.69 percent over a period of 152 years between 1800 and 1953. Between 1953 and 1963 the population of Benin City increased at a decreasing rate of 80.61 percent. Furthermore, the growth rate decreased to 77.23 in 1983 but increased again to 142.73 percent in 1991 . Given the total population as 1,086,882 in 2006, the growth between 1991 and 2006 was 42.50 percent.

Table 2: Population Changes in Benin City

\begin{tabular}{|c|c|c|}
\hline Year & Population & \% Change \\
\hline$* 1800$ & 15,000 & - \\
\hline 1953 & 55,753 & 271.69 \\
\hline 1963 & 100,694 & 80.61 \\
\hline 1983 & 178,457 & 77.23 \\
\hline${ }^{\star} 1987$ & 435,197 & 38.50 \\
\hline 1991 & 762,717 & 142.73 \\
\hline$\star \star 2000$ & $1,039,507$ & 36.29 \\
\hline 2006 & $1,086,882$ & 4.56 \\
\hline${ }^{*} 2008$ & $1,164,295$ & 7.12 \\
\hline
\end{tabular}

Sources: *Ikhuoria (1984)

${ }^{*}$ Authors' projection based on official growth rate of 3.5\% per annum for urban settlements in Nigeria.

National Population Commission Census results are unmarked

\subsection{Trend and Pattern of Growth in Benin City}

Three distinct growth phases were identified in Benin City between 1987 and 2008. However, the premise was provided by Ikhuoria (1984) who traced the growth and development of Benin City between 1800 and 1979. Ikhuoria found that Benin City had a total built up area of 486 hectares (ha) in 1938 which increased to 7,413.7 ha in 1979 (Table 3).

Table 3: Built up Area Statistics of Benin City (1800-1979)

\begin{tabular}{|c|c|}
\hline Year & Area (Ha) \\
\hline 1800 & 384.2 \\
\hline 1938 & 486.0 \\
\hline 1952 & 944.5 \\
\hline 1963 & $2,217.6$ \\
\hline 1972 & 3000 \\
\hline 1979 & $7,413.7$ \\
\hline
\end{tabular}

Source: Ikhuoria, (1984) 


\subsubsection{Growth Extent of Benin City, 1980 to 1987}

Figure 3 displays the growth extent of Benin City in 1987. Between 1980 and 1987, major physical expansion in the study area occurred towards the south and north-western part of the city. Growth was also identified at the eastern part of the city across the Ikpoba River. Growth along this axis was discovered to have been aided by the presence of the Ikpoba River Bridge which links the eastern part of the country with the city and the location of beverage industries which served as a growth pole around the area. Growth can be noticed to be emerging along route ways leading out of the city in the south-eastern, south-western, north-western and northern parts of the city. Built-up area occupies approximately $34,997.46$ hectares representing $14.79 \%$ of the total land use/ land cover. The built-up area concentrated within the central part of the city although not without pockets of vegetation land cover. It was also found to exist within the periurban area of the city indicating an emerging sprawl.

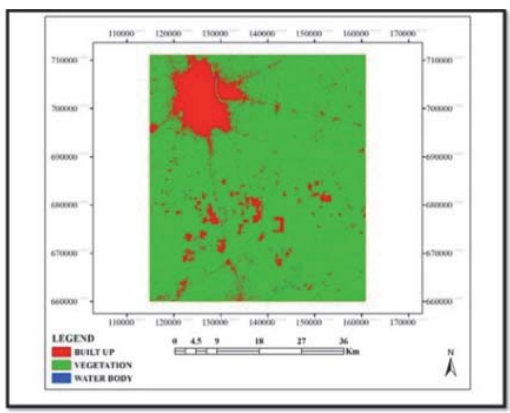

Figure 3: Growth Extent of Benin City, 1987

Source: Landsat TM 1987 Landuse Classified Image

Table 4: Landsat 1987 Land use/ land cover Statistics

\begin{tabular}{|l|c|c|c|}
\hline Land use Type & Area $(\mathrm{Ha})$ & Area $\left(\mathbf{k m}^{2}\right)$ & \% of Total Land Area \\
\hline Built-up Area & 34997.46 & 349.98 & 14.79 \\
\hline Vegetation & 201067.37 & 2010.67 & 84.96 \\
\hline Water body & 600.45 & 6.0 & 0.25 \\
\hline Total Land Area & $\mathbf{2 3 6 6 6 5 . 2 8}$ & $\mathbf{2 3 6 6 . 6 5}$ & $\mathbf{1 0 0}$ \\
\hline
\end{tabular}

Source: Generated from Fig. 3

\subsubsection{Growth Extent of Benin City, 1988 - 2000}

Figure 4 shows classified Landsat TM imagery for the year 2000. The image shows a more pronounced sprawl being experienced at the fringes of the city. Patches of vegetation that were visible within the built up area in the image of 1987 are no longer visible on that of 2000.

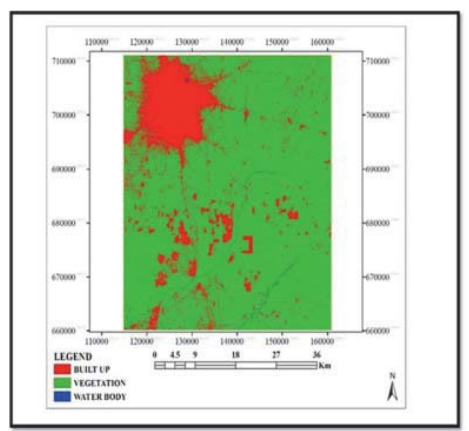

Fig. 4: Growth Extent of Benin City in 2000

Source: Landsat TM 2000 Landuse Classified Image 
Table 5: Growth Extent of Benin City in 2000

\begin{tabular}{|l|c|c|c|}
\hline Land use Type & Area $(\mathrm{Ha})$ & Area $\left(\mathbf{k m}^{2}\right)$ & \% of Total Land Area \\
\hline Built-up Area & 53329.57 & 533.30 & 22.53 \\
\hline Vegetation & 183305.59 & 1833.06 & 77.45 \\
\hline Water body & 30.12 & 0.30 & 0.01 \\
\hline Total Land Area & $\mathbf{2 3 6 6 6 5 . 2 8}$ & $\mathbf{4 1 1 3 4 . 1 2}$ & $\mathbf{9 9 . 9 9}$ \\
\hline
\end{tabular}

Source: Generated from Fig. 4

From Table 5, the built up area of Benin City has increased to $53,329.57$ ha which is about $22.53 \%$ of the total land area. This represented an increase of $7.74 \%$ over that of 1987 . While vegetation occupied $183,305.59$ ha (77.45\%) with a decrease of $7.51 \%$ and water body covers 30.12 ha $(0.01 \%)$ decreasing by $94.98 \%$ (7.3\% per annum).

\subsubsection{Growth Extent of Benin City, 2001 - 2008}

Fig. 5 shows a greater expansion of the built areas and an increased incidence of sprawl at the city fringe area. The construction of a by-pass road from Upper Sakponba road in the south through the eastern axis to Ugbowo-Lagos road in the north created opportunity for expansion of the built-up area along these corridors. This resulted to the development of a new core at the southern part.

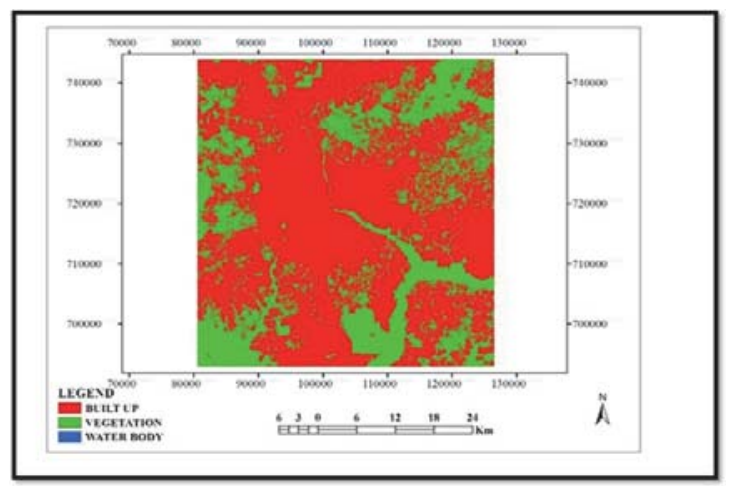

Fig. 5: Growth Extent of Benin City, 2008

Source: Landsat ETM+ 2008 Landuse Classified Image

Table 6: Growth Extent of Benin City in 2008

\begin{tabular}{|l|c|c|c|}
\hline Land use Type & Area $(\mathrm{Ha})$ & Area $\left(\mathbf{k m}^{2}\right)$ & \% of Total Land Area \\
\hline Built-up Area & 119539.27 & 1195.39 & 50.51 \\
\hline Vegetation & 117106.93 & 1171.07 & 49.48 \\
\hline Water body & 19.08 & 0.19 & 0.01 \\
\hline Total Land Area & $\mathbf{2 3 6 6 6 5 . 2 8}$ & $\mathbf{2 3 6 6 . 6 5}$ & $\mathbf{1 0 0}$ \\
\hline
\end{tabular}

Source: Generated from Fig. 5

In 2008, the built-up area of the city increased to $119,539.27$ ha (50.51\%) and vegetation land cover had decreased to $117,106.93$ hectares (49.48\%) and vegetation land use/land cover is now 19.08 hectares (0.01\%). The rate of growth change process of the study area is contained in Table 7. 
Table 7: Rate of Growth Change

\begin{tabular}{|l|c|c|c|c|}
\hline Land use Type & $\mathbf{1 9 8 7}$ & $\mathbf{2 0 0 8}$ & Actual Change & \% Change \\
\hline Built up & 34997.46 & 119539.27 & 84541.81 & 11.7 \\
\hline Vegetation & 201067.37 & 117106.93 & -83960.44 & -2.0 \\
\hline Water body & 600.45 & 19.08 & -581.37 & -4.6 \\
\hline
\end{tabular}

The negative sign indicates a decreasing rate of change.

Source: Adapted from Tables 2 to 6.

\subsection{Discussion}

The nature and spatial pattern of urban sprawl in Benin City clearly fits into the models of urban structure such as the concentric zone, sector and the multiple-nuclei theories. Concentration of economic activities at the core attracted sellers at the periphery who view the high human agglomeration at the city centre as an opportunity to increase their economic gains. In addition, the spatial spread of commercial centres for the sale of specialized goods such as the Mission road (north-eastern part of the city), Ring Road/Mission Road, the eastern part (Ikpoba Hill Market) and south-eastern zones (Oka Market). Other areas of intense commercial activities are the old core area of the city, (King's Square and Akpakpava Street), Airport road (south-western part of the city) and the University of Benin area along Lagos road at the northern part of the city. This radial circulation system provided avenue for the agglomeration of people at different parts thereby enhancing a strong basis for interaction within every part of the city.

The commercial areas which were also identified as the growth centres support the postulate of Harris and Ullman's (1945) multi-nuclei theory which pre-supposes several centres of economic activities generating human agglomeration. The increasing spatial spread of these commercial centres indicates increasing level of commercial activity. For example, the electronics market at the Mission Road/New Lagos Road axis has expanded to more than a 30 metre radius into the Ring Road area. However, this has resulted to increasing demand for housing at the core and the corresponding inadequate supply.

The trend in rent values was observed to be high around the city center and decreases towards the outskirts which are typically low density areas of the city. Also there are other areas of mixed low and high density buildings. In effect, land rent was high closer to the core of the city. The rise in the land costs along Ugbowo/New Lagos Road was as a result of the location of the University of Benin in that area. Individuals acquired houses in that area majorly for the construction of hostels which are rented out to students at high prices.

Before 2008, Amagba and Evbukhu were the only areas desired for farmlands as they were typically rural areas. The recent rise in demand for housing development in Evbukhu was found to been spurred by the discovery of a new oil well in the area. This has attracted Federal Government presence through the Nigerian National Petroleum Corporation (NNPC) as well as other oil-producing companies. Another major factor that was found to have aided the increase in demand for lands in the city was the inability of government to control landed properties. People from neighbouring Local Government Areas like Orhionmwon and States like Delta took advantage of such a benevolent opportunity to acquire lands and build structures.

The relationship between population and built up land use indicated that built up area was increasing with increasing population. However, there was a negative relationship between population and vegetation changes in the study area. Thus, it follows that increase in population leads to increase in the built up land use and, consequently decrease in the vegetation land cover.

The result of the slope and intercept regression analysis is presented in Table 8. The trend in time series is indicated by the strength and direction of the correlation coefficient $(r)$ while the rate of this trend is indicated by the value of the slope of the regression.

Table 8: Slope and Intercept Regression Table

\begin{tabular}{|l|c|c|c|c|c|c|c|}
\hline Variable & Slope & Intercept & $\mathbf{r}$ & $\mathbf{P}$ & $\mathbf{r}^{2}$ & mse & d.f \\
\hline Built-up Area & 0.1155 & -4849 & 0.9344 & 0.2318 & & & \\
\cline { 1 - 5 } Vegetation & -0.1147 & 2.8409 & -0.9325 & 0.2353 & \multirow{2}{*}{0.8066} & \multirow{2}{*}{5.075} & 3 \\
\hline Water Body & -0.0008 & 1061.4 & -0.8966 & 0.2921 & & \\
\hline
\end{tabular}


The built-up land use area had a regression coefficient of 0.9344 indicating a significant relationship between population and the built-up area. The slope value of 0.1155 indicates that for every unit increase of population there was a corresponding increase of 0.1155 hectares in the built-up area. Vegetation land cover has a regression coefficient of 0.9325 indicating that there was no significant relationship between vegetation and population. Vegetation decreased at a rate of 0.1147 ha for every unit increase in population. In addition, there was an insignificant relationship between water body and population with a regression coefficient of -0.8966 . This indicates that water body decreased at the rate of 0.0008 ha for a unit increase in population.

\subsection{Factors Responsible for the Growth Pattern of Benin City}

a) Accessibility was a major factor that influenced the growth of such areas as Iwogban along Taboga/Upper Mission Road and Elema/Oko/Ogba (Airport Road). Between 1997 and 2008, Oregbeni (Aduwawa/BeninAsaba Road) had the highest growth basically because of the presence of expressway.

b) In most cases, cost of land and the space required/ available were considered with accessibility. Low cost of land in Oregbeni along Aduwawa/Benin-Asaba Road attracted more land developers to the area because it was easy to obtain relatively larger portion of land.

c) Nature of the land was also identified as key factor that influenced the growth of certain parts of the study area. Evbogida/Use (Siluko road) experienced high occurrences of flooding and thus received the lowest growth response.

d) The influence of urban sprawl was evident in the growth and development of Amagba and Evbukhu which were previously local communities at the fringes of Ikpoba-Okha Local Government Area.

\subsection{Predicting Physical Growth of Benin City to 2050}

Using the geometric growth model, the physical elements and population of Benin City are projected to the year 2050 (Table 9). Based on this, Cellular Automata Model of landuse forecasting was used to predict changes in the built up area of Benin City.

Table 9: Projected Population and Land Use/Land Cover Statistics (2020-2050)

\begin{tabular}{|l|c|c|c|c|}
\hline Elements & $\mathbf{2 0 2 0}$ & $\mathbf{2 0 3 0}$ & $\mathbf{2 0 4 0}$ & $\mathbf{2 0 5 0}$ \\
\hline Population & $2,068,395$ & $2,917,676$ & $4,115,670$ & $5,805,573$. \\
\hline Built up (ha) & $1,348,312.14$ & $4,076,876.21$ & $12,327,053.82$ & $37,272,714.57$ \\
\hline Vegetation (ha) & $15,636.73$ & $-69,003.26$ & $-172,180.97$ & $-297,952.91$ \\
\hline Water body (ha) & -1447.74 & -2951.88 & -5310.22 & -9007.86 \\
\hline
\end{tabular}

Source: Authors' Computation, 2013).

\section{Conclusion}

The intricate dynamics involved in urban growth an unending process; one study emerging as a solution or reaction to another results in becoming a problem or thesis for the next stage. To enjoy the benefits of urban development, sustainable urban growth and sustainable development are usually advocated. This study used Remote Sensing and GIS tools to monitor urban growth in Benin City over a period of twenty-one years (1987 - 2008).

This study has revealed that Benin City actually experienced significant expansions at three different periods between 1987 and 2008. Significant physical expansions in the study area were found to the north, east, south and south-eastern parts of the city. In addition, it was revealed that greatest occurrence of this growth occurred between the 2000 and 2008. Growth and development of axial corridors was the major factor determining the direction of city spread; urban development was found to gear towards areas with easy access to the city centre. Problems attached to the growth and expansion of the study area were found to range from poor development control, poor waste management, and road traffic related problems like traffic congestion, traffic delays and dilapidating road infrastructures to social vices like theft and burglary. 


\section{Implications of the Study}

The expansion of Benin City is a function of many factors as identified in the previous section. It follows therefore that by the year 2050, if the population of Benin City stands at 5,805,573 as projected, it is expected that the city will be left with only $385,505.9$ hectares of its total area. This is likely to have impact on human health. The natural bush cover is being removed without any consideration for replacement, thus there is the tendency for reduction in the amount of carbon dioxide in circulation. Consequent upon this, there is likely to be a change in the environmental conditions in terms of rainfall and temperature. The expansion of population at the periphery can be attributed to preference for low-density housing and the suburban lifestyle. Therefore, much agricultural area has been used for urban built-up. This finding is consistent with that of Tokyo (Hasi and Yoshiki, 2012).

Another major problem attached to the growth of Benin City was uncontrolled land use development particularly at the suburban. Associated with this are problems of increased traffic congestion, inadequate transportation facilities and poor circulation system in newly developing areas, flooding, erosion, poor waste management and shortage of basic facilities. This is in line with Burak and Karen (2008) who opined that by 2020 all developable land will be urban and the increase in the number of vehicles will be a major source of air pollution.

In view of these problems, it is recommended that rather than engage in a reactive approach to urban planning, the Edo State Department of Town Planning should be proactive and contemporary in its approach to urban planning. Remote sensing and GIS technique should therefore be used to monitor Benin City's civil infrastructure such as the roads and their current conditions, flood analysis, identifying, monitoring and delineation of forest areas, tracking urban sprawl or growth and solid waste management. Thus, in line with Fabiyi (2006) who posited that the monitoring of urban growth is a major concern that has been frustrated by lack of up to date information, it is necessary to provide a basis for a more effective understanding and management of the urban environment.

For efficient urban planning and in the attempt to provide for a sustainable urban growth, the existing social infrastructures within the city centre should incorporate the suburbs. The peripheral regions should be consciously mobilised to receive, adopt and effectively apply innovations emanating from the core regions of the city. Hence, service centres should be created at the fringes to reduce the daily influx of population to the city centre.

Considerations should also be given to improving the efficacy of the waste management board through developing a waste management database system and regularizing the waste disposal routine. Rather than relying on reactive planning measures the State Department of Town Planning should develop a master plan that will be more proactive to the changing dynamics of the city.

\section{References}

Ade, M. A. and Afolabi, Y. D. (2013). "Monitoring Urban Sprawl in the Federal Capital Territory of Nigeria Using Remote Sensing and GIS Techniques" Ethiopian Journal of Environmental Studies and Management 6(1), 82-95.

Adepoju, M. (2005). "Sensing for Sprawl" http://www.hero.ac.uk/sites/hero/uk/business/archives/2005/sensing forsprawl.cfm?view=print.

Bhatta, B., Saraswati, S. and Bandyopadhyay, D. (2010). "Quantifying the degree-of-freedom, degree-of-sprawl, and degree-ofgoodness of urban growth from remote sensing data". Elsevier: Applied Geography, 30, 96-111

Burak, G. and Karen, C. S. (2008). "Environmental impacts of urban growth from an integrated dynamic perspective: A case study of Shenzhen, South China". Elsevier: Global Environmental Change, 18, 720-735.

Chen, L., Yuzhe, W., Qiping, S., and Hao, W. (2013). "Driving force of urban growth and regional planning: A case study of China's Guangdong Province". Elsevier: Habitat International, 40, 35 - 41

De Sherbinin, A.; Balk, D.; Jaiteh, M.; Pozzi, F. ;Giri, C. and Wabbebo A., (2002). A CIESIN thematic guide to Social Science Applications of Remote Sensing, retrieved from http:/sedac.ciesin. columbia.edu/tg/guide_main.jsp.

European Environment Agency (2006). EEA Report No 10/2006. Retrieved from http://www.reports. eea. europa.eu/eea_report 2006_10/en/eea_report_10_2006.pdf

Fabiyi, O. O. (2006) Urban Land Use Change Analysis of a Traditional City from Remote Sensing data: The case of Ibadan metropolitan area. Humanity and Social Sciences Journal 1 (1), $42-64$.

Hasi, B. and Yoshiki, Y. (2012) Landsat analysis of urban growth: How Tokyo became the world's largest megacity during the last 40 years. Elsevier: Remote Sensing of Environment, 127, 210-222

Hossein, S. M., and Marco, H. (2013). Spatiotemporal urbanization processes in the megacity of Mumbai, India: A Markov chains-cellular automata urban growth model. Elsevier: Applied Geography, 40, 140 - 149

Ikhuoria, I. A. (1986). Spot Satellite Detection and Analysis of Urban Spatial Growth Regimes in a Pre-colonial African City. Japur Press Ltd.

National Population Commission of Nigeria (1991) Results of 1991 Population Census.

National Population Commission of Nigeria (2006) 2006 National Population Census Results. 
National Research Council (2003) Using Remote Sensing in State and Local Government: Information for Management and Decision Making: National Academic Press.

Rahman, A, Netzband, M., Singh, A., and Mallick, J. (2007). An Assessment of Environmental Issues Using Remote Sensing and GIS Techniques: an Integrated Approach. A Case Study: Delhi, India. Retrieved from http://www.populationenviornmentresearch.org Iworkshops.jsp\#W

Shupeng C, Shan, Z and Chuangji, X. (2000). "Geospatial Technology in China", Journal of the American Society for Photogrammetry and Remote Sensing, 56(5), 35-43.

Srvastava, V. K. (2002). "Application of Remote Sensing and G.I.S. Techniques in Monitoring of Urban Sprawl in and around Jharia Coalfields, (Dhanbad)", http://www.gisdevelopment.net/application/urban/sprawl/urbans0002pf.htm.

UN-Habitat, (2008). The State of the World's Cities, 2008/2009". Earthscan, London

Weng, Q. (2001). "Modelling of Urban Growth Effects on Surface Runoff with the Integration of Remote Sensing and GIS", Environmental Management, 28(6), 737-748. 